Науковий вісник НЛТУ України
Scientific Bulletin of UNFU
$\begin{gathered}\text { http://nv.nltu.edu.ua } \\ \text { https://doi.org/10.15421/40290711 } \\ \text { Article received 28.08.2019 p. }\end{gathered}$

В. П. Шлапак

Уманський національний університет садівництва, м. Умань, Україна

\title{
РЕЗЕРВИ ПІДВИЩЕННЯ ЛІСИСТОСТІ ТА ПРОДУКТИВНОСТІ КУЛЬТУР СОСНИ У ЦЕНТРАЛЬНО-ПРИДНІПРОВСЬКІЙ ВИСОЧИННІЙ ОБЛАСТІ
}

\begin{abstract}
Досліджено, що Центрально-Придніпровська височинна область відзначається надзвичайно низьким відсотком лісистості та майже суцільною розораністю. Встановлено, що за раціонального ведення лісового господарства у регіоні досліджень, резервом для підвищення лісистості $є$ прирічкові землі, землі, непридатні для подальшого сільськогосподарського використання і землі покинутих людьми сіл, які були збудовані у басейнах водозборів великих і малих річок. Виявлено, що ліси водозбору представлені лісовими масивами, полезахисними, протиерозійними, придорожніми смугами, трапляються невеликими фрагментами на схилах долини, зрідка виходять на плакор, а серед зональної рослинності збереглися дубово-ясеневограбові ліси. У чагарниковому ярусі має перевагу ліщина звичайна, рідше - клен татарський, бруслина бородавчаста та європейська. Водночас уздовж русла, особливо у пониззі, формуються заплавні вербово-тополеві ліси, а у верхів'ях водозабору - заплавні вільшняки. 3'ясовано, що для підвищення продуктивності соснових насаджень Чигиринського бору у випадках, коли догляд своєчасно не здійснювався і лісостан формувався в умовах високої повноти, інтенсивність рубань для середньовікових і пристигаючих насаджень доцільно підвищити на $1015 \%$. Наступні прийоми доглядових рубань необхідно проводити традиційними селекційними методами через 4 роки, оскільки простежується зміна глобальної температури за останні 175 років у бік потепління. Висвітлено наслідки введення робінії псевдоакації як міжквартального бар'єру за залісення Чигиринських пісків. Пропонуємо як систему протипожежних заслонів проти поширення вогню у соснових культурах у ролі міжквартальних бар'єрів використовувати насадження берези повислої, а не робінії псевдоакації. Земельні наділи покинутих людьми сіл пропонуємо заліснювати деревостанами на типологічній основі з урахуванням головних лісотвірних порід місцевості.
\end{abstract}

Ключові слова: насадження; водозабір; землі; культури; лісистість; запас стовбурової деревини.

Вступ. Підвищення ефективності лісового господарства можливе тільки на зонально-типологічній основі, оскільки зональний підхід забезпечує раціональне використання лісових ресурсів. За висловлюваннями К. Б. Лосицького (Lositsky, 1961), регіональні особливості ведення лісового господарства зумовлені закономірностями розміщення та відновлення головних лісотвірних порід і лісових формацій, продуктивністю деревостанів, потенційними можливостями лісорослинних умов, віковою структурою та будовою насаджень. Водночас, варто зауважити, що ліси в Центрально-Придніпровській височинній області розташовані на водозборах малих і великих річок і відрізняються наявністю деревної та чагарникової рослинності, тому належать як до природних фізико-географічних факторів формування водного балансу, так і до антропогенних факторів, виступаючи у ролі об'єкта господарської діяльності людини (Mikhovich, 1986; Moroz \& Shlapak, 2000).

Постановка проблеми. Як дослідив А. С. Генсірук (Gensiruk, 1992), лісистість України в I тисячолітті нашої ери становила 44,4 \%, а нині у Держлісфонді вона не перевищує 15,6\%. У Центрально-Придніпровській височинній області сучасний рівень лісистості (15,9\%), а нерівномірність у розміщенні лісів зумовлена діяльністю людини. Так, тільки за останні три століття пло- ща лісів Лісостепу зменшилась у 4,5 раза. Ще у XVIII ст. ліси займали майже суцільні території від Дністра до Дніпра, де зростали переважно дубові ліси з ясенем, черешнею, грабом, кленом, в'язом і берестом. У понижених місцях траплялися береза, осика, вільха. Соснові ліси займали піщані і супіщані, найбідніші на поживні речовини, грунти річкових терас. У Лісостепу зосереджено 28,7 \% площі лісового фонду держави (ShelyagSosonko, 1974). Лучні різнотравно-злакові степові ландшафти знаходяться тепер під сільськогосподарськими угіддями (Kuzemko, Shiryaeva \& Spryagaylo et al., 2017).

Середні температури липня на північному заході становлять $+18{ }^{\circ} \mathrm{C}$, на півдні $+22{ }^{\circ} \mathrm{C}$; січня $-5-8{ }^{\circ} \mathrm{C}$, найнижчі температури зареєстровано на сході $36{ }^{\circ} \mathrm{C}$. Тривалість періоду з середньодобовими температурами від +5 до $+15^{\circ} \mathrm{C}$ становить на заході 100110 діб, на лівобережжі Дніпра - 8090 діб. Безморозний період триває на заході 190180, на сході - 160150 діб. Річна сума опадів на заході зони становить 550750, на сході450 мм, а випаровуваність відповідно 550 і 750 мм. Найбільше опадів (6575\%) буває влітку. Весняний стік річок досягає $4260 \%$ річного. Переважає снігове та дощове живлення, частка підземних вод незначна (до $10 \%$ ) (Agrometeorological, 2016).

Поширеними грунтами в Лісостепу є мало- і се-

\section{Інформація про авторів:}

Шлапак Володимир Петрович, д-р с.-г. наук, професор, завідувач кафедри лісового господарства. Email: shlapakwp@gmail.com Цитування за ДСтУ: Шлапак В. П. Резерви підвищення лісистості та продуктивності культур сосни у Центрально-придніпровській височинній області. Науковий вісник НлтУ України. 2019, т. 29, № 7. С. 50-59.

Citation APA: Shlapak, V. P. (2019). Reserves for Increasing Afforestation and Productivity of Pine Cultures in the Central-Prydniprovsky Highland Area. Scientific Bulletin of UNFU, 29(7), 50-59. https://doi.org/10.15421/40290711 
редньогумусні типові чорноземи, опідзолені чорноземи і темно-сірі лісові грунти. Здебільшого на терасах Дніпра трапляються піщані і супіщані грунти. У річкових долинах лучні, дернові та болотні грунти. Однак загальна заболоченість зони незначна $-1,6 \%$.

Природних лісів у Лісостепу, як зазначають О. I. Фурдичко, Г. Б. Гладун, В. В. Лавров (Furdychko, Gladun \& Lavrov, 2006), П. І. Мороз, В. П. Шлапак (Моroz, Shlapak, 2000), M. I. Гордієнко та ін. (Gordienko et al., 2007; Gordienko et al., 2002), майже не збереглося, оскільки ця зона з найдавніших часів була центром землеробської культури. Як дослідили С. А. Генсірук (Gensiruk, 1992), Ю. Р. Шеляг-Сосонко (Shelyag-Sosonko, 1974), територія сучасної Черкащини була вкрита переважно дубовими лісами, де окрім сосни звичайної і дуба звичайного, росли граб звичайний, ясен звичайний, клен гостролистий і польовий, липа серцелиста і дрібнолиста, в'яз, берест, рідше черешня, береза, осика, вільха чорна і сіра, береза повисла, груша звичайна, яблуня звичайна. Соснові ліси займали відносно бідні грунти річкових терас. Похідні грабняки, що ростуть у дібровах, займають немалі площі. Ясеневі насадження переважають майже у всіх районах Черкаської області.

Водночас найбільший інтерес, 3 погляду практики ведення лісового господарства у регіоні досліджень, становить лісистість території та шляхи їі підвищення. Нині резервом для підвищення лісистості є залісення прирічкових земель та земель, непридатних для подальшого сільськогосподарських використання, а також земель покинутих людьми сіл. Проблематичними є доглядові рубання та використання робінії псевдоакації у ролі протипожежних бар'єрів у соснових насадженнях.

Програма, об'єкти та методика проведення дослідження. Програмою експериментальних досліджень передбачалося розкрити резерви підвищення лісистості за рахунок залісення прирічкових земель, земель, непридатних для подальшого сільськогосподарського використання та земель покинутих людьми сіл, вивчення продуктивності соснових насаджень, використання робінії псевдоакації і берези повислої як протипожежного бар'єру в соснових культурах.

Об'єктами дослідження є водозабір річки Гірський Тікич, сільськогосподарські землі Смілянського агропромислового комплексу та землі покинутих сіл с. Жолудькове Маньківського р-ну, культури сосни і протипожежні лісові бар'єри в ДП "Чигиринське лісове господарство".

Методика виконання робіт є загальноприйнятою для лісівничих і таксаційних досліджень 3 використанням методів узагальнення, компонентного аналізу, логістичного та історичного підходу. Визначення оптимальної водоохоронної лісистості та річного стоку під впливом зміни лісистості проводили за методичними розробками 3 використанням таблиць і графіків, розроблених А. Г. Міховичем (Mikhovich, 1969, 1976, 1976, 1986).

Обговорення результатів дослідження. Загальна площа земель лісового фонду, за даними Державного агентства лісових ресурсів (Forest map of Ukraine 2005) становить 10,8 млн га, 3 яких вкрито лісовою рослинністю 9,5 млн га. Середній щорічний приріст у лісах становить 4,0 $\mathrm{m}^{3} \cdot \mathrm{ra}^{-1}$, зокрема до $3,0 \mathrm{~m}^{3} \cdot \mathrm{ra}^{-1}$ у лісостеповій зоні. Як повідомляють О. І. Фурдичко, Г. Б. Гладун, В. В. Лавров (Furdychko, Gladun \& Lavrov, 2006), на від- міну від країн східної Свропи, лісистість яких становить 43,2 \%, середня лісистість України сягає 15,6 \% території (табл. 1).

Табл. 1. Лісистість держав Європи

(Furdychko, Gladun \& Lavrov, 2006)

\begin{tabular}{|c|l|c|c|c|}
\hline $\begin{array}{c}\text { № } \\
3 / \Pi\end{array}$ & Країна & $\begin{array}{c}\text { Загальна площа } \\
\text { території країни, } \\
\text { тис. га }\end{array}$ & $\begin{array}{l}\text { Площа вкритих лі- } \\
\text { сом земель, тис. га }\end{array}$ & $\begin{array}{c}\text { Лісис- } \\
\text { тість, \% }\end{array}$ \\
\hline 1 & Швеція & 45218 & 27264 & 60,3 \\
\hline 2 & Фінляндія & 33814 & 21883 & 64,7 \\
\hline 3 & Франція & 54919 & 15156 & 27,6 \\
\hline 4 & Іспанія & 50596 & 13509 & 26,7 \\
\hline 5 & Німеччина & 35702 & 10740 & 30,1 \\
\hline 6 & Туреччина & 77945 & 9954 & 12,8 \\
\hline 7 & Італія & 30132 & 9857 & 32,7 \\
\hline 8 & Україна & 60355 & 9458 & 15,6 \\
\hline 9 & Польща & 31268 & 8942 & 28,6 \\
\hline 10 & Норвегія & 32376 & 8710 & 26,9 \\
\hline
\end{tabular}

Згідно 3 даними табл. 1, за загальною площею території Україна $є$ однією 3 найбільших країн Європи (60355 тис. га), а площа вкритих лісом земель становить 9458 тис. га, або 15,6 \% території. За лісистістю це трішки більше Туреччини - 12,8 \%. Лісистість Європи, за винятком України і Туреччини, знаходиться в межах 26,9 (Норвегія) - 64,7 (Фінляндія) 64,7 \%).

Як дослідили В. П. Ткач В. Л. Мешкова (Tkach \& Meshkova, 2019), оптимальна лісистість, за якої ліс найбільш позитивно впливає на клімат, грунти, якість води, забезпечує найбільшу продуктивність для України, повинна становити $20 \%$, а для досягнення такого рівня лісистості площа лісів нашої держави має сягати 12 млн га, тобто додатково потрібно створити близько 2,5 млн га лісових насаджень. У зоні Лісостепу це 450 тис. га, що становить $18 \%$. Тому ведення лісового господарства в лісах державного лісового фонду з урахуванням залісення водозборів річок, залісення непридатних для подальшого використання сільськогосподарських земель та залісення земельних наділів покинутих людьми сіл, як вагомого резерву в підвищенні показника лісистості, повинна стати однією 3 основних сучасних проблем лісової галузі України.

Проблему оптимальної лісистості досліджували такі вчені, як: Ю. П. Бялович (Bialovich, 1972), М. М. Глєбов (Glebov, 2007), А. Г. Міхович (Mikhovich, 1969, 1976, 1976, 1986), А. А. Молчанов (Molchanov, 1966), В. П. Ткач, В. Л. Мешкова (Tkach \& Meshkova, 2019) та ін. Водночас, як свідчать дослідження В. С. Олійника (Oliynik, 2008), ліси у чотири рази зменшують вірогідність виникнення повеней. У своїх роботах А. I. Міхович (Mikhovich, 1986), А. А. Молчанов (Molchanov, 1966), А. С. Братцев (Brattsev \& Brattsev, 1990) зазначають, що лісові насадження по-різному виконують свої екологічні функції, зокрема і водоохоронні. Найповніше виконують екологічні функції стиглі деревостани, що необхідно обов'язково враховувати за ведення лісового господарства на водозборах річок.

За даними інституту гідробіології НАН України за останні 80 років з карти України зникло більше 3 тис. малих річок і струмків. Тепер така доля чекає таких невеликих річок, як Кам'янка - головної водної артерії всесвітньо відомого Дендрологічного парку "Софіївка", Гнилий Тікич, Ірдинка та безліч інших. Тому встановлення оптимальної лісистості водозбирання, яка підвищить повноводність річок, на прикладі річки Гірський Тікич, є актуальною і необхідною, що дасть змогу убез- 
печити малі річки від обміління і підвищити показник лісистості в Державі.

Вперше про обмеження рубання лісу навколо великих і малих річок зустрічаємо в царських указах Петра I (Redko \& Shlapak, 1993), де він обмежує втручання біля великих річок на 50, а малих 20 км "никому ни на какие нужды не рубить и валежнику не брать", а ідею ведення господарства на водозбірній основі запропонував В. В. Докучаєв (Dokuchaev, 1936). Його ідеї про ведення лісового господарства з урахуванням водозборів річок було відображено у рекомендаціях IX Всесвітнього лісового конгресу, який відбувся у Мехіко в 1985 р. Тоді було вперше визнано, що водозбір $є$ елементарною територіальною одиницею щодо ведення лісового господарства.

Досліджуючи можливість залісення водозборів річок з'ясовано, що західні та південні райони Центрально-Придніпровської височенної області відзначаються надзвичайно низьким відсотком лісистості та майже суцільною розораністю. Природна та напівприродна рослинність цього регіону збереглася тільки у долинах річок. Особливо цінними природними територіями західної частини Черкащини є ландшафти долини річки Гірський Тікич, яка протікає в межах Оратівського району Вінницької області та Монастирищенського, Жашківського, Маньківського і Тальнівського районів Черкаської області (басейн Південного Бугу, рис. 1). Довжина річки 167 км, площа басейну 3510 км².

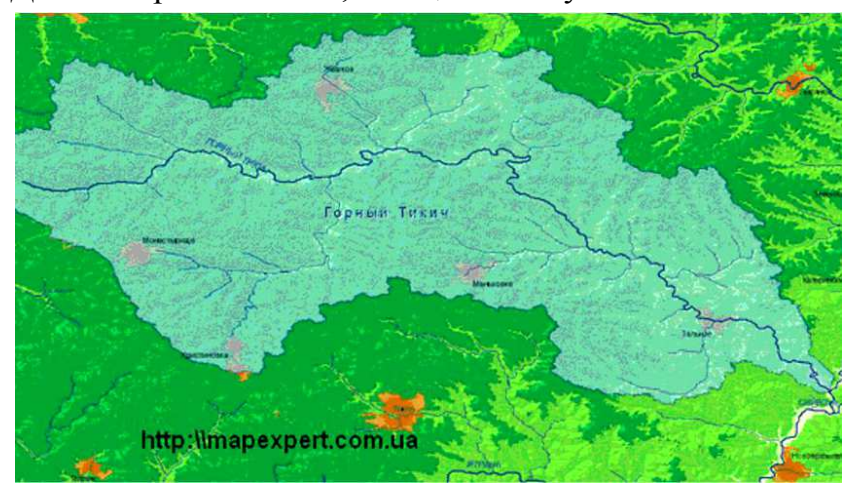

Рис. 1. Водозбірний басейн річки Гірський Тікич

Долина завширшки до 23 км, похил річки 0,78 м/км. Річище звивисте, береги підвищені, кам'янисті. $€$ водоспади (водоспад "Вир") та пороги. Біля смт Буки річка утворює Буцький каньйон. Живлення снігове і дощове. Річка характеризуються унікальною геоморфологічною будовою, зумовленою виходами на земну поверхню порід Українського кристалічного щита, різноманітним рослинним покривом із поєднанням лісової, степової, лучної, болотної, водної та петрофітної рослинності (Kuzemko et al., 2017). Живлення снігове і дощове. Річка характеризується унікальною геоморфологічною будовою, зумовленою виходами на земну поверхню порід Українського кристалічного щита, різноманітним рослинним покривом із поєднанням лісової, степової, лучної, болотної, водної та петрофітної рослинності (Kuzemko, Shiryaeva, Spryagaylo et al., 2017). Долина Гірського Тікича характеризується малим відсотком залісення, що характерно для західної частини Черкаської області.

Найбільші лісові масиви розташовані біля с. Антоніна Монастирищенського р-ну (урочище Центральне), на межі Маньківського і Тальнівського р-нів (урочище Великий ліс) та неподалік с. Глибочок Тальнівського р- ну (урочище Ворончик). Однак, загалом, за дослідженням Генсірука (Gensiruk, 1992), А. I. Міховича (Mikhovich, 1969), Д. Л. Соколовського (Sokolovsky, 1968), ліси водозбору переважно представленні мілкими та більш крупними лісовими масивами, полезахисними, протиерозійними, придорожніми смугами, а А. А. Куземко і ін. (Kuzemko, Shiryaeva, Spryagaylo et al., 2017), уточнюють, що на водозаборних територіях ліси трапляються невеликими фрагментами на схилах долини, інколи виходять на плакор. Уздовж русла, особливо у пониззі, формуються заплавні вербово-тополеві ліси, а у верхів'ях - заплавні вільшняки. Серед зональної рослинності збереглися дубово-ясенево-грабові ліси, деревний ярус яких сформований дубом, ясенем і грабом. У чагарниковому ярусі переважають ліщина звичайна, клен татарський, бруслини бородавчаста та європейська. Водночас, варто зауважити, що ліси на водозборах річок належать як до природних фізико-географічних факторів формування водного балансу, так і до антропогенних факторів, виступаючи у ролі об'єкта господарської діяльності людини.

Тому розглянемо процес впливу лісових насаджень водозабору річки Гірський Тікич на атмосферні опади, поверхневий стік, сумарне випаровування та величину грунтового стоку. Графічні моделі використано з досліджень А. Г. Міховича (рис. 2, $a$ ).

Дані для розрахунків лісистості водозабору річки Гірський Тікич взято з матеріалів особистих досліджень А. Г. Міховича (Mikhovich, 1969, 1976, 1986) і літературних джерел стосовно різних стаціонарів на території України. Водночас, варто зауважити, що нормативи водоохоронної лісистості, розраховані А. Г. Міховичем, не були враховані для визначення оптимальної лісистості, оскільки їх дотримання призвело б до зменшення орних земель, а це за радянських часів було недопустимим (Furdychko, Gladun \& Lavrov, 2006). Зауважимо, що нормативи водоохоронної лісистості, які розрахував А. Г. Міхович (Mikhovich, 1969, 1976, 1976, 1986), базуються на результатах дослідження 150 басейнів річок, із яких 30 репрезентують Полісся, 52 - Лісостеп і $68-$ Степ. Водоохоронну роль лісу він визначав за різницею рівнянь водного балансу річкового водозбору вкритих і не вкритих лісом земель. Основою розрахунків А. Г. Міховича було положення, що за оптимальних значень водоохоронної лісистості максимально збільшується підземна складова річкового стоку. Розрахунки виявили, що на вкритих лісом площах кількість опадів у Лісостепу збільшується на 40 мм, а випаровування - на 50 мм.

За первинними даними складових водного балансу річкових водозборів будували графіки залежності змін опадів, поверхневого стоку і сумарного випаровування від частки лісистості за таблицями А.Г. Міховича, в яких наведено значення підземної складової річкового стоку за рівнів лісистості з інтервалом 1 \% (99, 98, 97 і т. п до $1 \%$ ). За цими даними визначено, за якої лісистості відбувається максимальне збільшення підземного стоку, що і є часткою водоохоронної лісистості. Було доведено, що максимальне збільшення підземного живлення річок відбувається не за $100 \%$ лісистості, а за меншої: у Поліссі - 45-60 \%, у Лісостепу - 20-40 \%, у Степу - 15-19 \%, тобто збільшення лісистості понад ці значення не призводить до збільшення водоохоронної ролі лісу. 

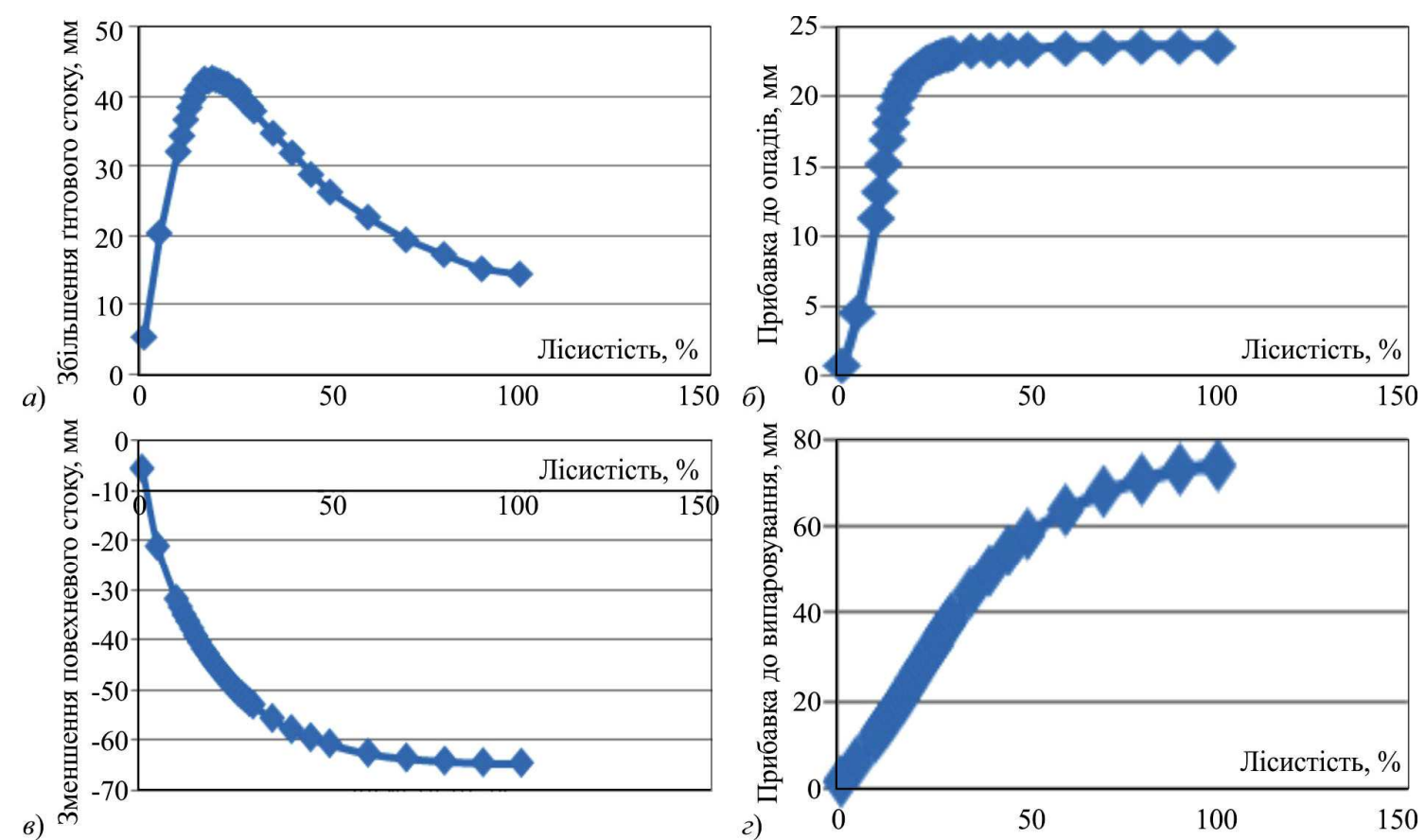

Рис. 2. Прибавка до грунтового стоку за різної лісистості водозбору (а); зміна кількості опадів за різної лісистості водозбору (б); зменшення поверхневого стоку за різної лісистості водозбору (в); вплив лісистості водозбору на випаровування (г)

Для досліджуваного водозбору річки Гірський Тікич характерне швидке зростання приросту показника грунтового стоку за збільшення лісистості від 1 до $25 \%$ (див. рис. 2,a). Найбільших значень грунтовий стік досягає за лісистості $1535 \%$, за максимального - $25 \%$. Подальше зростання лісистості сприяє повільнішому збільшенню складової грунтового стоку. За збільшення лісистості водозбору понад $40 \%$ зменшується приріст грунтового стоку.

Оптимальна водоохоронна лісистість річки Гірський Тікич повинна становити 2530 \%. За відповідної лісистості спостерігатиметься прибавка до грунтового стоку на рівні 30 мм (215\%) від початкової величини грунтового стоку, тобто грунтовий стік збільшиться у 3,6 раза. За зміни лісистості у бік збільшення або зменшення позитивний вплив лісових насаджень на підземну складову річкового стоку значно послаблюється.

Інтенсивний приріст атмосферних опадів спостерігається за лісистості близько $25 \%$ (див. рис. 2,б). Прибавка до атмосферних опадів становить 33 мм, або $6 \%$ від фактичної кількості опадів. За подальшого збільшення лісистості приріст атмосферних опадів менш інтенсивний. Поверхневий стік спостерігається тільки після випадання опадів та інтенсивного танення снігу. До поверхневого стоку відносять тільки ті води, які стікають по поверхні та дрібних елементах рельєфу. Поверхневий стік виникає у випадку, коли інтенсивність опадів перебільшує інфільтраційну здатність грунту. Як дослідив Дж. Кітредж (Ketridge, 1951), ліси зменшують поверхневий стік та сприяють збільшенню підгрунтового стоку, підвищенню водопроникності грунту, що змінює поверхневий стік та переводить його у підземний.

Сумарне випаровування є однією з головних витратних складових водного балансу. Молоді та середньовікові деревостани мають вищий показник сумарного випаровування порівняно з більш літніми, а збільшення випаровування спостерігається за підвищення продуктивності та повноти. Високоповнотним деревостанам характерне збільшення сумарного випаровування.
За результатом аналізу математичних моделей зміни складових водного балансу водозбору річки Гірський Тікич за різної лісистості вирахувано, що за збільшення лісистості водозбору спостерігається зменшення поверхневого стоку (див. рис. 2,8), але підвищення випаровування (див. рис. 2,г). Кількісний показник поверхневого стоку за оптимальної водоохоронної лісистості на рівні $20 \%$ зменшується у середньому на 50 мм, або на $60 \%$, а показник випаровування підвищиться тільки на 6 мм, або $1,8 \%$, тоді як грунтовий стік збільшується на 17 мм, або $95 \%$ від фактичного розміру відповідного показника. Водночас максимальна зміна у показнику поверхневого стоку спостерігається за суцільного залісення водозбору.

У своїх працях В. П. Ткач та В. Л. Мєшкова (Tkach $\&$ Meshkova, 2019) зазначають, що оптимальною лісистістю визначена така структура лісів: частка прирічкових насаджень $-37,8 \%$; протиерозійних $-26,5 \%$; полезахисних - 5,7 \%; придорожніх - 1,0\%; зелених зон $4,3 \%$; інших $-24,7 \%$. Частка прирічкових насаджень $\epsilon$ найбільшою в оптимальній структурі лісів України, що свідчить про пріоритетність водоохоронної лісистості, що деякою мірою $є$ виправданим, зважаючи на значну протяжність та розгалуженість річкової мережі, а також про позитивний вплив насаджень на складові водного балансу за умови дефіциту питної води в Україні.

Під час детального вивчення та обстеження земельних ресурсів Смілянського р-ну в 1995 р. було встановлено, що 344573 га сільськогосподарських угідь, в тому числі ріллі 43375 га, змиті грунти займають 41,6\% від площі обстежених угідь. Водночас, варто зазначити, що в деяких господарствах цей показник змінювався від 20 до 85,3 \% (Rimar, Shlapak \& Punko, 1995). Нині $є$ чимало земель, непридатних до подальшого сільськогосподарського використання. Вони заростають чагарниками і перетворюються у низькопродуктивні хащі. Державні підприємства лісового господарства повинні взяти на свій баланс захаращені пустирі, яруги, ерозійні балки і залісити їх, а колективні та приватні господарства повинні профінансувати залісення. Проте органи 
місцевого самоврядування не поспішають передавати ці землі лісівникам. Самі не використовують і не передають, а таких "покинутих" земель у регіоні досліджень щонайменше 50 тис. га. У громад немає ні фахівців, ні фінансового ресурсу, аби впорядкувати та залісити яри, балки чи косогори.

Однак у 2019 р. впродовж лісокультурної кампанії, у зоні Центрально-Придніпровської височенної області, лісові культури створено на загальній площі 1089 га. Зокрема, висаджено понад 10 млн сіянців: сосни звичайної на 441 га, закладено ділянки дуба звичайного на 482 га та горіха чорного на 73 га та ін. Шляхом лісорозведення створено 30 га нових лісів на непридатних землях для подальшого сільськогосподарського використання.

Землі покинутих людьми сіл можуть бути резервом для підвищення лісистості не тільки Черкаської обл., але й України загалом (Shlapak \& Isaev, 2016). 31991 p. 3 мапи України зник 641 сільський населений пункт, зокрема 40 селищ і 601 село (Electronic resource: http://tyzhden.ua/News/77330). 31991 по 2012 р. в Україні зникло 528 сільських населених пунктів, серед яких 34 селища й 494 села через відсутність у них жителів, а ще через об'єднання 3 іншими населеними пунктами, або через включення їх у межі міст чи селищ міського типу зникло 113 сільських населених пунктів, серед яких 6 селищ і 107 сіл. 2000 р. став рекордним для України щодо відмирання сіл. Тоді 3 адміністративного

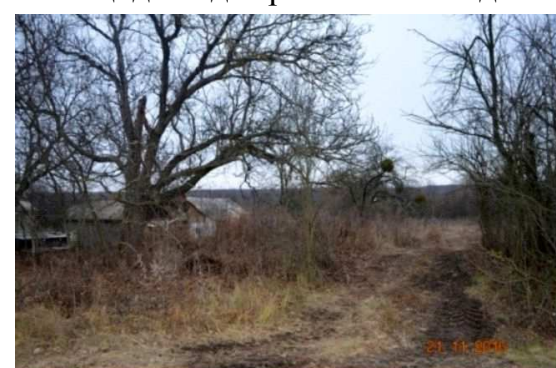

Рис. 3. Залишена людьми садиба в с. Жолудькове Маньківського району

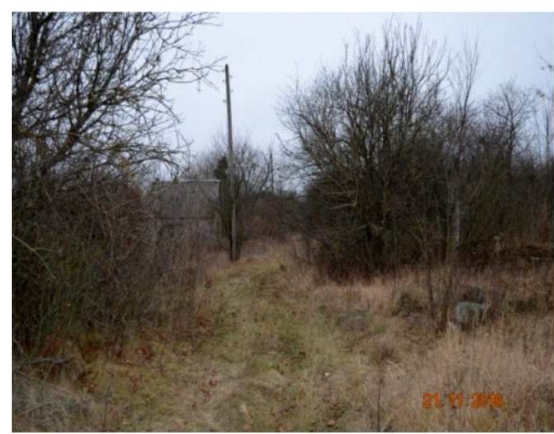

Рис. 6. Стан вулиці в селі Ясківці Чигиринського району

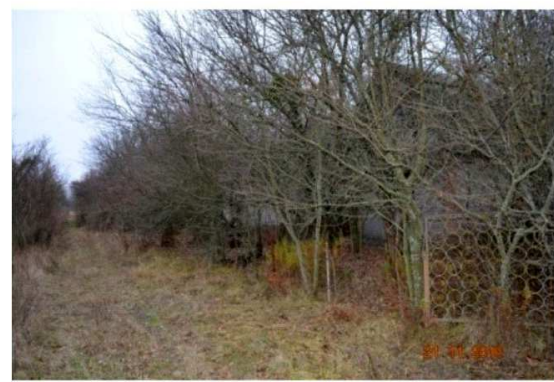

Рис. 9. Вулиця і покинуті людьми садиби заросли деревною рослинністю

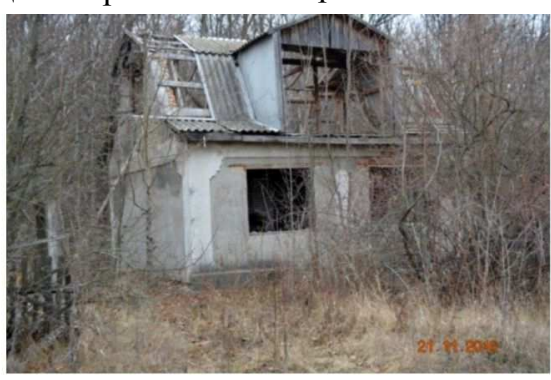

Рис. 4. Залишена людьми дача в с. Жолудькове Маньківського району

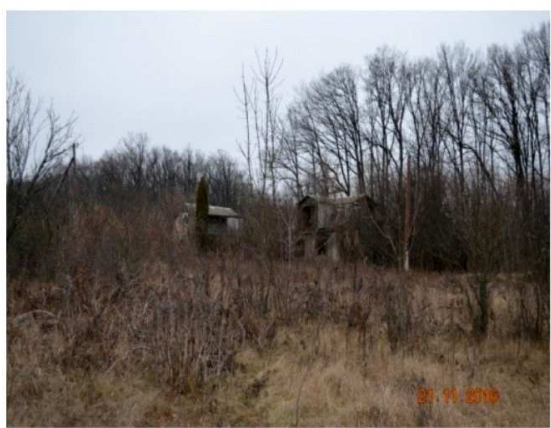

Рис. 7. Залишені садиби в стані розпаду в селі Жолудькове

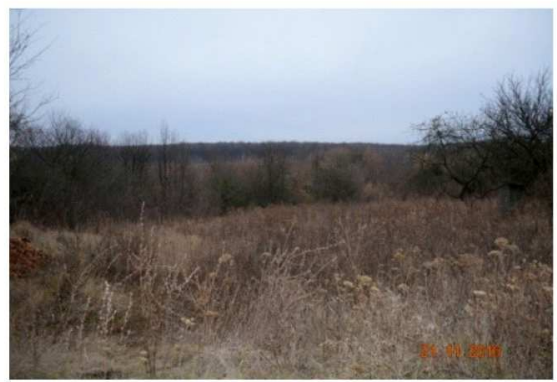

Рис. 10. Зарослі рудеральною рослинністю людські огороди в селі Жолудькове

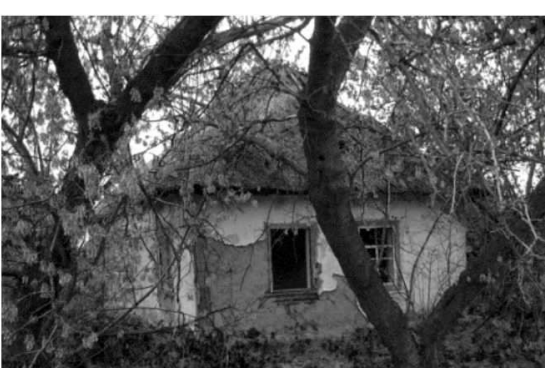

Рис. 5. Покинута людьми садиба в селі Ясківці Чигиринського району

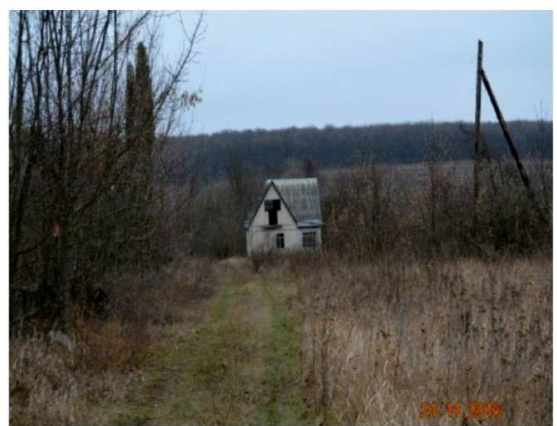

Рис. 8. Заросла присадибна ділянка рудеральною рослинністю с. Жолудькове

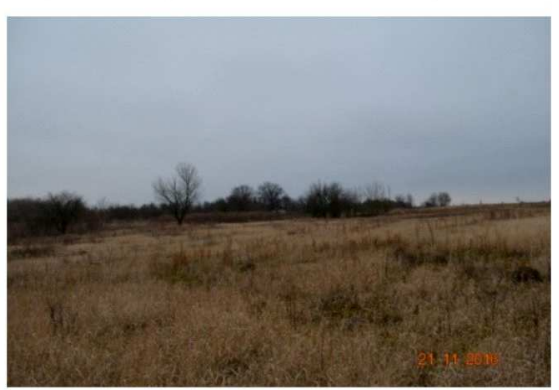

Рис. 11. Заросли рудеральною рослинністю покинуті сільськогосподарські землі в селі Жолудькове 
За нашими дослідженнями, для заміни низькопродуктивних різновидових порід необхідно провести реконструкцію насаджень, а на землях колишніх сільськогосподарських наділів мешканців села рекомендуємо створювати чисті дубові та соснові культури садінням 3 шириною міжрядь 2,0-2,5×07 м 3 головної (дуб, сосна) та супутніх (липи, клена, граба, плодових) порід 3 обов'язковим уведенням у культури чагарників (свидини, бузини, аморфи й ліщини) за деревно-чагарниковим типом змішування. На тракторопрохідних чорноземах та піщаних землях культури доцільно створювати рядовим способом, що дасть змогу механізувати трудомісткі лісокультурні роботи із передпосадкового обробітку грунту, садіння сіянців та агротехнічні догляди за грунтом. В окремих місцях найпоширенішими способами створення лісових культур дуба звичайного на пустинних землях доцільно застосувати шпигування жолудів, а також використати сучасні методи створення часткових культур дуба і суцільних культур на землях, що вийшли 3-під сільськогосподарського користування. висіванням жолудя за схемою $4 \times 0,5$ м, а садінням сіянців за схемою $4 \times 0,7$ м. Це забезпечить густоту культур у кількості 5000 та 3570 шт. га $^{-1}$ відповідно. Доречно також зазначити, що на сьогодні територія безлюдних сіл сягає до 0,7 млн га, а з урахуванням покинутих дачних наділів ця територія може збільшитися до 1 млн га.

Притясминські бори належать до інтрозональних природних лісових формацій Середнього Подніпров'я, де впродовж тисячоліть формувались високопродуктивні деревостани сосни звичайної (Pinus sylvestris L.), (Brovko, Shlapak, 2016). Однак основною особливістю цих борів $\epsilon$ те, що вони під впливом антропогенних чинників утратили природну самобутність і $є$ рукотворними. Різноманітні прийоми створення і вирощування насаджень у борах позитивно вплинули на формування лісового середовища. Розглядаючи приуроченість природних піщаних комплексів до терас річки Тясмину, відзначено, що для першої борової тераси характерні дрібногорбисті з висотою горбів до 3 м і частково середньогорбисті піски заввишки до 7 м. Для другої борової тераси - навіяні високогорбисті піски 3 висотою горбів від 7 до 30 м. Завершується ця тераса різким переходом високогорбистих пісків у рівнину з чорноземно-супіщаними грунтами, які $\epsilon$ характерними для третьої тераси р. Тясмину. Перша спроба залісити піски пов'язана 3 професором 3. С. Голов'янком, який упродовж 1902-1905 рр. створив культури сосни звичайної на площі 500 га. Нині їх залишилось 140 га. Вони ростуть за I і II класами бонітету і мають запас стовбурної деревини у межах 280-460 $\mathrm{m}^{3} \cdot \mathrm{ra}^{-1}$ (табл. 2).

Аналізуючи дані, наведені у цій таблиці, варто зазначити, що культури сосни створені в сухих $\left(\mathrm{B}_{1}\right.$-ДС) та свіжих $\left(\mathrm{B}_{2}\right.$-ДС) суборових умовах зростання. Загалом суборові типи лісу займають 51,3 \% площі бору. Із них на сухі субори ( $\left.\mathrm{B}_{1}-Д С\right)$ припадає $65,0 \%$ їх площі, на свіжі - 35,0. Середній діаметр змінюється від 24,7 до 37,4 см, а середня висота - від 24,6 до 29,2 м. Як видно 3 табл. 2, тип лісорослинних умов вплинув на запас стовбурної деревини тільки у культурах, що ростуть у кварталі 13 виділ 20, де він становить $461 \mathrm{~m}^{3} \cdot \mathrm{ra}^{-1}$. В інших насадженнях особливих розходжень не встановлено. Відмінність можна пояснити певними прорахунками в агротехнологічних прийомах створення і вирощування культур, зокрема, переважно невчасними доглядовими рубаннями лісу. Найменша істотна різниця за всіма показниками знаходиться в допустимих межах, що свідчить про достовірність проведених досліджень.

Табл. 2. Лісові культури сосни звичайної, 0441творені за участі проф. З. С. Голов'янка (Чорнявське лісництво) (Shlapak, Shlapak, 2003).

\begin{tabular}{|c|c|c|c|c|c|c|c|c|c|}
\hline \multirow{2}{*}{ № кв. } & \multirow{2}{*}{ № вид. } & \multirow{2}{*}{$\begin{array}{c}\text { Площа, } \\
\text { га }\end{array}$} & \multirow{2}{*}{$\begin{array}{c}\text { Рік } \\
\text { посадки }\end{array}$} & \multicolumn{2}{|c|}{ Середні } & \multirow{2}{*}{ Бонітет } & \multirow{2}{*}{ тЛУ } & \multirow{2}{*}{ Повнота } & \multirow{2}{*}{$\begin{array}{l}\text { Запас, } \\
\text { м }^{3} \cdot \mathrm{ra}^{-1}\end{array}$} \\
\hline & & & & $\mathrm{D}, \mathrm{cm}$ & $\mathrm{H}, \mathrm{m}$ & & & & \\
\hline 13 & 20 & 13,0 & 1904 & 34,2 & 29,2 & $\mathrm{I}^{\mathrm{a}}$ & $\mathrm{B}_{2}$-ДС & 0,7 & 461 \\
\hline 13 & 26 & 7,3 & 1904 & 32,7 & 26,4 & I & $\mathrm{B}_{1}-Д \mathrm{C}$ & 0,7 & 370 \\
\hline 14 & 9 & 21,0 & 1902 & 29,6 & 26,8 & I & $\mathrm{B}_{1}-Д \mathrm{C}$ & 0,7 & 390 \\
\hline 23 & 3 & 15,0 & 1904 & 26,2 & 24,7 & II & $\mathrm{B}_{1}-Д \mathrm{C}$ & 0,6 & 281 \\
\hline 23 & 13 & 25,0 & 1903 & 28,4 & 27,5 & I & $\mathrm{B}_{2}-Д \mathrm{C}$ & 0,6 & 321 \\
\hline 22 & 2 & 30,0 & 1903 & 24,7 & 24,6 & II & $\mathrm{B}_{1}-Д \mathrm{C}$ & 0,6 & 370 \\
\hline 22 & 17 & 28,5 & 1904 & 37,4 & 25,8 & II & $\mathrm{B}_{1}-Д \mathrm{C}$ & 0,7 & 361 \\
\hline$\sum$ & & 139,8 & & & & & & & \\
\hline & & $\mathrm{HIP}_{0,95}$ & & 2,74 & 2,82 & & & & 2,56 \\
\hline
\end{tabular}

Табл. 3. Лісівничо-таксаційна характеристика 45-62-річних соснових культур

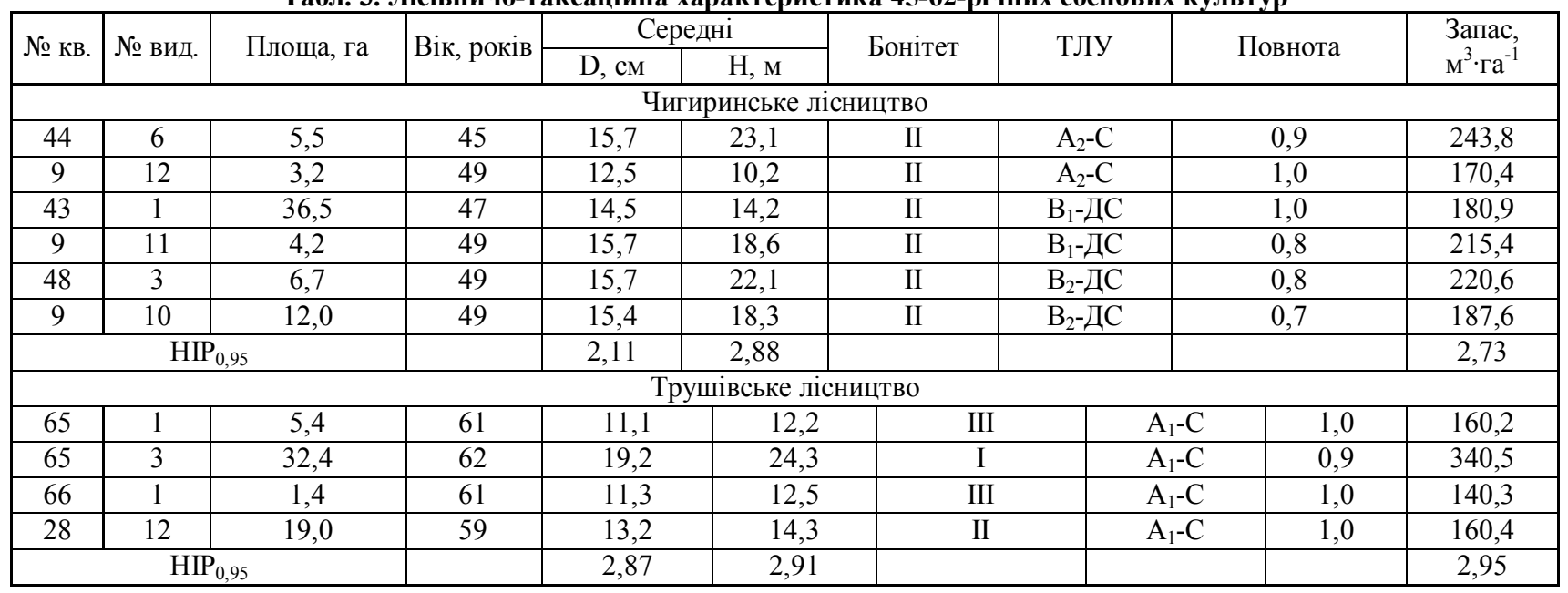


У період достигання ріст і розвиток дерев сосни в умовах Чигиринського і Трушівського лісництв залежить від типу їх онтогенезу і завершується у момент кульмінації приросту за об'ємом стовбурової деревини (табл. 3). У Чигиринському лісництві, як видно $з$ цієї таблиці, культури сосни створювалися на різних типах лісорослинних умов $\left(\mathrm{A}_{2}-\mathrm{C}, \mathrm{B}_{1}\right.$-ДС і $\mathrm{B}_{2}$-ДС), що вплинуло на запас стовбурової деревини тільки у культурах, що ростуть у кварталі 44 виділ 6 в умовах $\mathrm{A}_{2}-\mathrm{C}$, де він $\epsilon$ найбільшим 243,8 $\mathrm{m}^{3} \cdot \mathrm{ra}^{-1}$. В умовах $\mathrm{B}_{1}$-ДС і $\mathrm{B}_{2}$-ДС запас стовбурної деревини становить відповідно 215,4 i $220,6 \mathrm{~m}^{3} \cdot \mathrm{ra}^{-1}$ (рис. 12). Щодо Трушівського лісництва, то в кварталі 65 виділі 3 культури сосни мають найбільшу висоту (19,2 м) і діаметр (24,3 см), а запас стовбурної деревини $-340,5 \mathrm{~m}^{3} \cdot \mathrm{ra}^{-1}$.

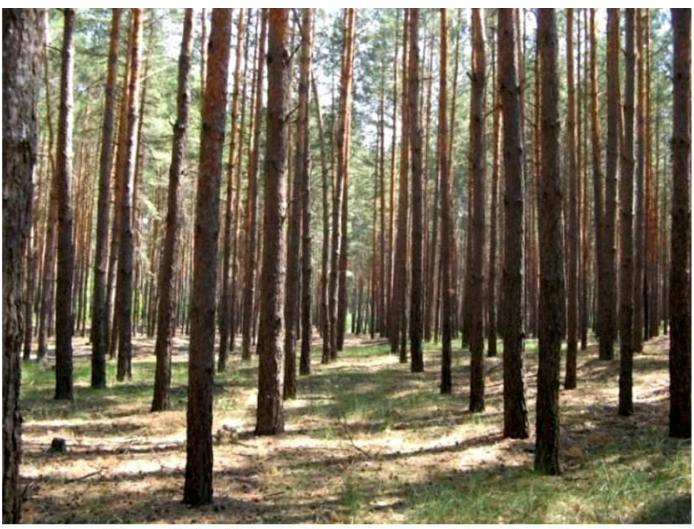

Рис. 12. Культури сосни звичайної у Чигиринському лісництві

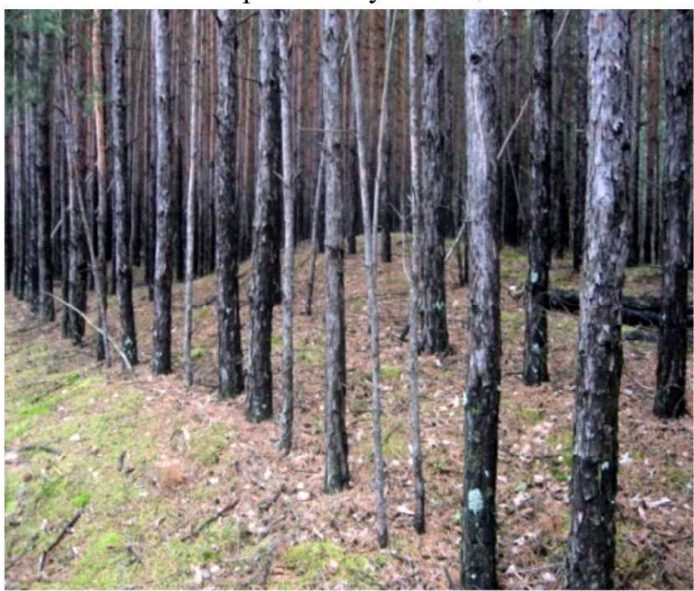

Рис. 13. Культури сосни, в яких не проводилося рубання взагалі (Трушівське лісництво)

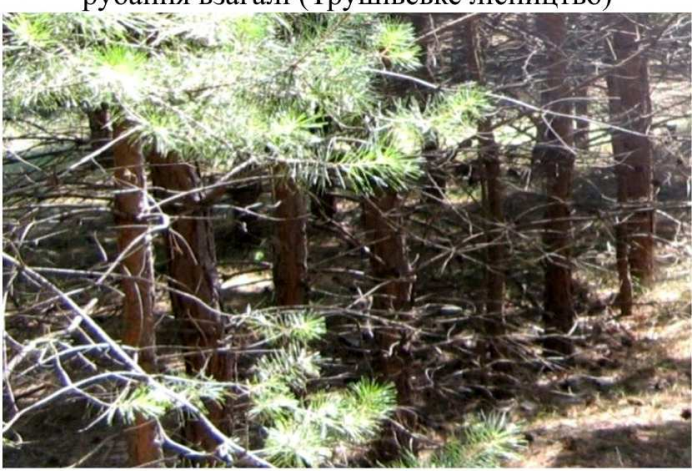

Рис. 14. Перегушені 60-річні культури сосни, які виросли без рубань

У інших насадженнях як Чигиринського лісництва, де середні діаметри значно менші, а запаси стовбурової деревини знаходяться в межах 170,4-187,6 $\mathrm{m}^{3} \cdot \mathrm{ra}^{-1}$, так і в Трушівському лісництві в умовах $\mathrm{A}_{1}-\mathrm{C}$ за повноти
1,0 запаси стовбурової деревини не перевищують 140,3$160,4 \mathrm{~m}^{3} \cdot \mathrm{ra}^{-1}$, що 2,12,-4 рази менше. Відмінність можна пояснити тільки невчасними доглядовими рубаннями лісу. Водночас, у кварталі 65 виділі 1 і у кварталі 66 виділі 1 та кварталі 28 виділі 12 до 60-річного віку жодного виду доглядових рубань не проводилося (рис. 13).

Найменша істотна різниця за всіма показниками знаходиться в допустимих межах, що свідчить про достовірність проведених досліджень. Нині, у перегущених 60-річних соснових культурах ДП "Чигиринське лісове господарство" (рис. 14) потрібно застосовувати лінійний метод рубання, де варто вибирати кожний п'ятий ряд із проведенням у незайманих рядах звичайного селекційного догляду. У випадках, коли догляд своєчасно не здійснювався і лісостан формувався в умовах високої повноти $(1,0)$, інтенсивність рубань доцільно підвищити для середньовікових і пристигаючих насаджень на 1015 \%. Наступні прийоми доглядів необхідно проводити традиційними селекційними методами. Рубаннями вибирають сухостійні, відмираючі й пошкоджені дерева, екземпляри 3 неправильною формою стовбура і крони. Насіннєві дерева, зазвичай, залишають на корені. Потрібно залишити також цінні твердолистяні породи (ясен, дуб), домішка яких дуже корисна.

В Україні більше 40 \% вкритих лісовою рослинністю ділянок зайнято хвойними деревними породами, 3 них $80 \%$ сосновими деревостанами, з яких більше половини становлять молодняки та середньовікові насадження, які є пожежонебезпечними. У Чигиринському бору в 1962-1965 pр. було залісено 11,7 тис. га піщаних земель сосною звичайною. Тепер це 60-70-річні культури (рис. 15,a,б). Для унеможливлення розповсюдження лісових пожеж на значній площі територію соснових культур розбили на квартали i, як систему протипожежних заслонів проти поширення вогню, використали насадження $з$ робінії псевдоакації, як 50-метровий міжквартальний бар'єр. Нині це друга генерація робінії псевдоакації (див. рис. 15,a).

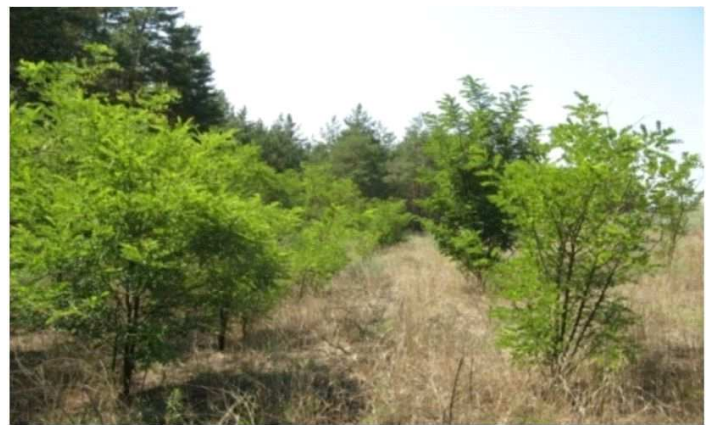

a) Robinia pseudoacacia (Трушівське лісництво)

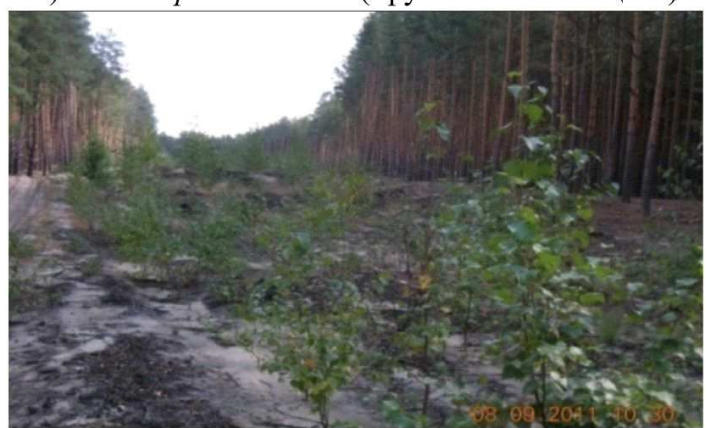

б) Betula pendula (Бірківське лісництво)

Рис. 15. Сучасний вид оновлених листяних бар'єрів 
Як наслідок непродуманого введення робінії псевдоакації в Державний лісовий фонд вона вегетативним шляхом проникла в культури сосни (див. рис. 15,a). Нині заслуговує на увагу досвід Бірківського лісництва ДП "Олександрівське лісове господарство" (див. рис. 15,б), де як систему протипожежних заслонів проти поширення вогню у хвойних лісах, використали насадження берези повислої.

Після суцільного рубання в ДП "Черкаське військове лісництво" були посаджені культури сосни (рис. 16). На третій рік робінія псевдоакація вегетативно і насіннєво відновилася насамперед у плужних борознах, а згодом поширилася на всю площу, заглушивши культури сосни (рис. 17 і 18).

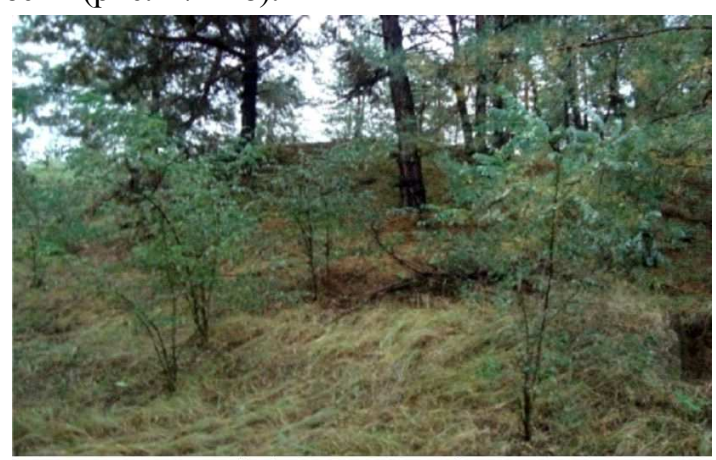

Рис. 16. Робінія псевдоакація вегетативно проникла у 60-річні культури сосни на 79 м. Чигиринське лісництво

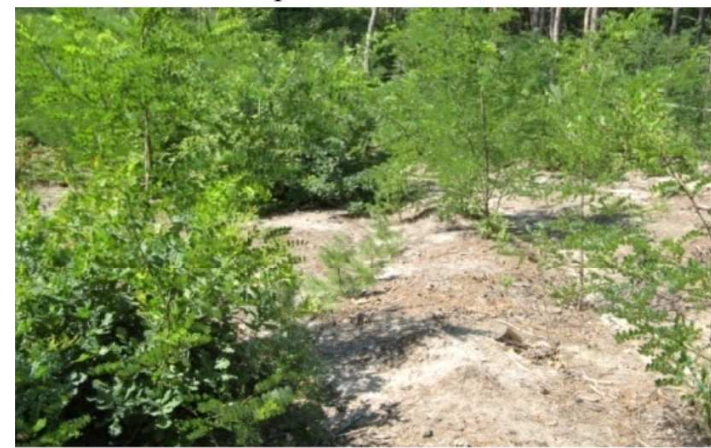

Рис. 17. Висота 3-річних культур сосни 2060 см, а робінії псевдоакації - до 3,5 м. 3-річних культур сосни відпад становив до 80 \%

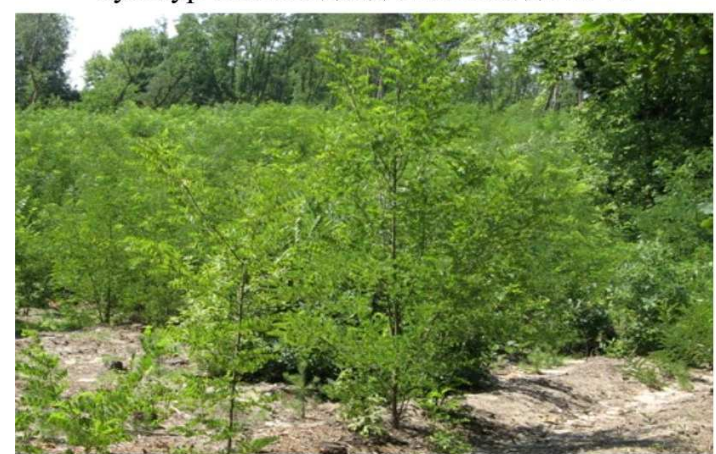

Рис. 18. Поширення робінії псевдоакації на всю лісокультурну площу

Клімат України за кількістю сонячної радіації, тепла та вологи $є$ сприятливим для росту і розвитку рослинності. Водночас особливості циркуляційних процесів сприяють формуванню різноманітності кліматичних умов, що призводить до різних гідрометеорологічних ускладнень та екстремальних явищ погоди, значна частка 3 яких - посушливість. За даними досліджень, проведених у США і Великобританії, за останні 175 років зафіксували однаковий хід глобального потепління. Як- що в 1850 р. було зафіксовано відхилення найхолодніших глобальних середньорічних значень температури повітря до $-0,3{ }^{\circ} \mathrm{C}$ за найбільшого зниження $-0,55{ }^{\circ} \mathrm{C}$, то через 100 років простежується початок підвищення глобальних позитивних температур до значення нульового показника, а починаючи 31980 -х років простежується підвищення глобальної температури до $+0,6^{\circ} \mathrm{C}$ i вище. Учені основним аргументом наводять парниковий ефект. Однак 3 цим висновком не всі погоджуються. Наша позиція така, якщо вважати, що планета є одинокою у Всесвіті, де зародилося життя тваринного i рослинного світів на поверхні Землі, то нібито все сходиться. Водночас, якщо вважати, що планета Земля i Сонячна система $є$ складовою частиною Галактики, то глобальне потепління варто шукати з позиції галактичного руху матерії. Якщо на Землі є пори року, то вони є в Сонячній системі і в Галактиці, оскільки вони перебувають у такому ж русі. Тому на них також $є$ зима 3 22 червня по 22 грудня, коли рослинний світ входить у стан спокою та завмирає і літо з 22 грудня по 22 червня, коли рослинний світ виходить зі стану спокою і розпочинається його ріст і розвиток. На наш погляд, якщо подивитися з такої позиції, то, очевидно, наша Сонячна система входить в Галактичне літо, тому на Землі відбувається потепління шляхом підвищення температури повітря. 3 високою вірогідністю цей процес пов'язаний 3 прецесійним рухом Землі, яка здійснює цей рух за 26 тис. років, 3 яких по 6,5 тисяч років у нашому розумінні зима, весна, літо, осінь. Це багато в чому пояснює висновки вчених, що 6,5 тис. років тому на Землі було заледеніння. В Україні льодовик дійшов майже до міста Дніпро, а наступні 6,5 тис. років танув, створюючи нинішній географічний ландшафт Землі. Тепер настала черга літа.

Вважаємо, що наша планета Земля знаходиться на шляху руху галактичної матерії, тому парниковий ефект в одній точці Сонячної системи не $є$ значущий. Це ніби запалити в кімнаті сірника і досліджувати зміну температури в кімнаті. Як тільки сірник потухне, матерія природно ліквідує неоднорідне середовище і приведе галактичну матерію в однорідний стан для подальшого іiі руху, тому парниковий ефект може деякою мірою створює якісь флуктуації, які не впливають на глобальне потепління. Глобальне потепління - це явище природи і людині непідвладне.

\section{Висновки:}

1. Центрально-Придніпровська височинна область відзначається недостатнім відсотком лісистості та майже суцільною розораністю. Водночас, за раціонального ведення лісового господарства у регіоні досліджень, резервом для підвищення лісистості є прирічкові землі, землі, непридатні для подальшого сільськогосподарського використання i землі покинутих людьми сіл, які знаходяться у басейнах водозборів великих і малих річок.

2. Ліси водозбору річки Гірський Тікич представлені мілкими та більш крупними лісовими масивами (урочища Центральне, Великий ліс та Ворончик) полезахисними, протиерозійними і придорожніми смугами на схилах долини. У пониззі русла формуються заплавні вербово-тополеві ліси, а у верхів'ях - заплавні вільшняки.

3. Серед зональної рослинності збереглися дубово-ясеневограбові ліси, але з переважанням грабняків. У чагарниковому ярусі переважають ліщина звичайна, клен татарський, бруслини бородавчаста та європейська. 
4. Ліси на водозборах річок належать як до природних фізико-географічних факторів формування водного балансу, так і до антропогенних факторів, виступаючи у ролі об'єкта господарської діяльності людини.

5. Фактична лісистість досліджуваного водозбору становить близько $9 \%$. Водночас інтенсивний приріст атмосферних опадів спостерігається за лісистості близько $25 \%$. Прибавка до атмосферних опадів становить 33 мм, або $6 \%$ від фактичної кількості опадів. Кількісний показник поверхневого стоку за оптимальної водоохоронної лісистості на рівні до $25 \%$ зменшується у середньому на 50 мм, або на $60 \%$, а показник випаровування підвищиться тільки на 6 мм, або 1,8 \%. Грунтовий стік збільшується на 17 мм, або $95 \%$ від фактичного розміру відповідного показника.

6. Максимальний позитивний вплив на складові річкового стоку ліси здійснюють не за суцільного, а за часткового залісення водозборів 20-40 \%. За збільшення або зменшення фактичної лісистості водозбору порівняно з оптимальною водоохоронною, позитивний вплив лісу на річковий стік зменшується в окремих випадках навіть до негативної дії.

7. За роки незалежності Україна втратила понад 800 сільських населених пунктів. За площею територія безлюдних сіл в Україні сягає до 0,8 млн га, а з урахуванням покинутих дачних наділів ця територія може збільшитися понад 1 млн га. Причинами зникнення сіл та зменшення чисельності сільського населення є демографічна криза, урбанізація та старіння нації. Перспективні сільські мешканці переїжджають у міста через безперспективність сільської глибинки, відсутність роботи, розвалена соціальна інфраструктура (не працюючі лікарні, школи, клуби), не дають змоги створити належні умови для організації життя на селі для молоді.

8. Формування ландшафтів та створення лісових культур на покинутих земельних наділах, які належать до зони формування борів і суборів та судібров і дібров, доцільно здійснювати на підставі результатів грунтово-типологічного обстеження прилеглих лісових масивів. На піщаних і супіщаних сільськогосподарських землях покинутих земельних наділів культури сосни звичайної потрібно створювати рядовим способом з розміщенням $2,5 \times 0,7$ м, а культури дуба рекомендується створювати висіванням жолудя за схемою $4 \times 0,5$ м та садінням сіянців за схемою $4 \times 0,7$ м, що забезпечить густоту культур у кількості 5000 та 3570 шт. га ${ }^{1}$ відповідно. Дотримання зазначених агротехнологічних прийомів дасть змогу механізувати трудомісткі лісокультурні роботи із передпосадкового обробітку грунту, садіння сіянців та агротехнічні догляди за грунтом.

9. У перегущених соснових насадженнях Чигиринського бору доцільно застосовувати лінійний метод рубання, де потрібно вибирати кожний п'ятий ряд із проведенням у незайманих рядах звичайного селекційного догляду. У випадках, коли догляд своєчасно не здійснювався і лісостан формувався в умовах високої повноти $(1,0)$, інтенсивність рубань для середньовікових і пристигаючих насаджень доцільно підвищити на 10-15\%. Наступні прийоми доглядів необхідно проводити традиційними селекційними методами.

10. Як систему протипожежних заслонів проти поширення вогню у соснових культурах Чигиринського бору варто відмовитися від міжквартальних бар'єрів з робінії псевдоакації, а за сучасної агротехнології використовувати насадження берези повислої.

11.31850 по 2000 pp. коливання глобальних температур повітря знаходиться в межах відповідно $-0,55$ та $+0,60{ }^{\circ} \mathrm{C}$. Нині простежується щорічне ії підвищення. Глобальне потепління - це явище природи і людині непідвладне.

\section{Перелік використаних джерел}

Bialovich, Yu. P. (1972). Standards of optimal woodland of the plain part of the USSR. Forestry and agroforestry, 54-65. Kiev: Harvest. [In Ukrainian].

Brattsev, S. A., \& Brattsev, A. A. (1990). Effect of forest productivity on the water balance of the Komi ASSR Taiga zone. Hydrological substantiation of water management measures: Proceedings of the $V$ All-Union Hydrological Congress. (pp. 674-679). [In Russian].

Brovko, F. M., \& Shlapak, V. V. (2016). Pine common on the Sands of Prytyasma. Kiev, 160 p. [In Ukrainian].

Dokuchaev, V. V. (1936). Our steppes before and now. Moscow, 102 p. [In Russian].

Forest map of Ukraine. (2005). Information sheet based on the materials of the State Forestry Committee of Ukraine. Kiev: Kiev Military Cartographic Factory. [In Ukrainian].

Furdychko, O. I., Gladun, G. B., \& Lavrov, V. V. (2006). Forest in the Steppe: basics of sustainable development. Kiev: Basis, 496 p. [In Ukrainian].

Gensiruk, S. A. (1992). Forests of Ukraine. Kiev: Science opinion, 407 p. [In Ukrainian].

Glebov, M. M. (2007). Formation of optimal forest cover of the Left Bank Ukraine on forest-typological basis. Forest typology in Ukraine: current state, prospects for development. Materials of the XIth Pogrebnyakov Readings. (pp. 54-55). Kharkiv: UkrNDILGA. [In Ukrainian].

Gordienko, M. I., Bondar, A. O., Rybak, V. O., \& Gordienko, N. M. (2007). Forest cultures of the plains of Ukraine. Kiev: Harvest, 667 p. [In Ukrainian].

Gordienko, M. I., Shlapak, V. P., Goychuk, A. F., Rybak, V. O., et al. (2002). Cultures of pine in Ukraine. Kiev: DOD of the institute of agricultural economics, 872 p. [In Ukrainian].

Ketridge, J. (1951). The effect of forest on climate, soil and water regime. Moscow: Published in Foreign Literature, 456 p. [In Ukrainian].

Khmelovska, O. (2013, 13 kvitnia). Za roky Nezalezhnosti z mapy Ukrainy znyklo 641 selo. Retrieved from: http://tyzhden.ua/News/77330. [In Ukrainian].

Kuzemko, A. A., Shiryaeva, D. V., Spryagaylo, O. V., Kostyushin, V. A., et al. (2017). National park "Mountain Tikich". Kiev, 16 p. [In Ukrainian].

Lositsky, K. B. (1961). On the question of optimal forest cover. Forestry publishing house, 11, 44 49. [In Ukrainian].

Mikhovich, A. I. (1969). Methods of quantitative assessment of the water regulation role of the forest. Kiev: Harvest, $22 \mathrm{p}$. [In Ukrainian].

Mikhovich, A. I. (1976). Influence of forest plantations on the river runoff of the territory of Ukraine. Proceedings of the 4th All-Union Hydrological Congress, 4, 488-492. [In Ukrainian].

Mikhovich, A. I. (1976). Optimal water conservation of the river basins of the plain part of the USSR. Forest and its role in environmental protection. Abstracts doc. All-Union Symposium with participation of foreign specialists. (pp. 58-60). [In Ukrainian].

Mikhovich, A. I. (1986). Water-protective afforestation. Kiev: Harvest, 142 p. [In Ukrainian].

Molchanov, A. A. (1966). Optimal woodland. Moscow: Science, 220 p. [In Russian].

Moroz, P. I., \& Shlapak, V. P. (2000). Complex development of the Middle Dnieper sand arrays. Lviv: Prestige Inform, 265 p. [In Ukrainian].

Oliunik, V. S. (2008). Redistribution of atmospheric precipitation by tent of the Carpathian mountain forests. Scientific Bulletin of $U N$ $F U, 18(6), 12-18$. [In Ukrainian].

Postrigan, V. S., \& Bazaeva, T. V. (Eds). (2016). Agrometeorological survey on the territory of Cherkasy region for 2015-2016 agricultural year. Cherkasu: Ukrainian Hydrometeorological Center, 43 p. [In Ukrainian].

Redko, G. I., \& Shlapak, V. P. (1993). Petr I on nature conservation and use of natural resources. Kiev: Libido, 176 p. [In Ukrainian]. 
Rimar, M. V., Shlapak, V. P, \& Punko, B. N. (1995). Land resources of the Smilyansko-Gorodishche agro-industrial complex. Cherkasy: RJV "Siach", 144 p. [In Ukrainian].

Shelyag-Sosonko, Yu. R. (1974). Forests of the oak formation in Ukraine and their evolution. Kiev, 239 p. [In Ukrainian].

Shlapak, V. P., \& Isaev I. S. (2016). Problems of afforestation of lands abandoned by people of villages in Ukraine. Prospects for the development of forestry and landscape gardening: Material of science sonference. (pp. 10-16). Uman: Vizavi. [In Ukrainian].
Shlapak, V. P., \& Shlapak, V. V. (2003). Golovyanko and his scientific activity. Science works of the Forestry Academy of Sciences of Ukraine, 2, 9-10. Lviv: Lviv Polytechnic. [In Ukrainian].

Sokolovsky, D. L. (1968). River drain (basics of theory and calculation method. Lviv: Gidrometeoizdat, 539 p. [In Ukrainian].

Tkach, V. P., \& Meshkova, V. L. (2009). Modern problems of optimization of Ukrainian forest cover. Retrieved from: http://dklg.kmu.gov.ua/forest/control/en/publish/article? art id $=62745 \&$ ca. [In Ukrainian].

V. P. Shlapak

Uman National University of Horticulture, Uman, Ukraine

\section{RESERVES FOR INCREASING AFFORESTATION AND PRODUCTIVITY OF PINE CULTURES IN THE CENTRAL-PRYDNIPROVSKY HIGHLAND AREA}

The author has studied reserves for the increase of afforestation and productivity of pine cultures in the Central Highland area of the Dnipro River. The area is characterized by insufficient forest cover and almost total plowing. Under the condition of using the rational forest management in the study area, riparian lands, lands which are unsuitable for further agricultural use and lands abandoned by the people of the villages, which were built in the basins of watersheds of the large and small rivers, are the reserve for the forest cover increase. The forests of the river watersheds are stated to be presented by woodlands, windbreaks, anti-erosion forests, road side trees, sometimes occur like small fragments on the valley slopes, rarely appear on the plateau, and among the zonal vegetation oak-ash-hornbeam forests are still preserved. Common hazel, rarely Tatarian maple, warted spindle tree and spindle tree prevail in the shrub layer. At the same time, floodplain willow-poplar forests are formed along the channels, especially in the lowlands, and in the highlands of the watershed flooded alders occur. It is proved that the maximum positive impact on the components of river runoff is carried out not by continuous but partial afforestation of the watershed. Under the condition of actual increase or decrease of the watershed forest cover compared to the optimal water protection, the positive impact of the forest on the river runoff decreases found, and in some cases even leads to a negative effect. To improve the productivity of pine plantations of Chygyryn pine forests in cases where care was not provided in time and the forest stands were formed in conditions of high completeness, the intensity of felling for middle-aged and premature stands should be increased by $10-15 \%$. The following methods of care felling should be carried out by traditional breeding methods in 4 years, as there is a change in the global temperature over the past 175 years towards warming. The consequences of black locust introduction as between quarter barrier during Chygyryn sand area afforestation are highlighted. We propose to use weeping birch instead of black locust in pine plantation as the between quarter barrier in a forest fire prevention system. It has been established that during the years of independence, Ukraine lost 641 rural settlements, including 40 villages and 601 small villages. The area of uninhabited villages in Ukraine has reached up to 0.7 million hectares, and with the account of abandoned suburban areas this area may increase to 1 million hectares. The causes of the disappearance of villages and the decline in rural population are the demographic crisis, urbanization, and aging of the nation. Therefore we suggest using afforestation on a typological basis on the land plots abandoned by the people of the villages, taking into account the main forest-forming species of the area.

Keywords: forest stands; watershed; areas; forest plantations; forest cover; standing timber reserves; abandoned villages; forest fire prevention. 